\title{
In vitro regeneration and secondary metabolites of Viola caspia subsp. sylvestrioides Marcussen
}

\author{
ZAHRA GHARARI $^{1 *}$, Ali SHARAFI ${ }^{2}$, KHADIJEH BAGHeRI ${ }^{1}$, ALIREZA YAZDINEZHAD ${ }^{2}$, SOROUSH BiJANi ${ }^{2}$ \\ ${ }^{1}$ Department of Plant Production and Genetics, Faculty of Agriculture, University of Zanjan, Zanjan, Iran \\ ${ }^{2}$ School of Pharmacy, Zanjan University of Medical Sciences, Zanjan, Iran
}

\begin{abstract}
Viola caspia subsp. sylvestrioides, a small important medicinal herb, belongs to the subsection Rostratae (sec. Viola) of genus Viola L. This study was performed to develop an efficient protocol for in vitro regeneration of $V$. caspia subsp. sylvestrioides as an ex situ technique for conservation of endangered plants and extraction of secondary metabolites. Leaf and petiole explants were cultured on half and full-strength Murashige and Skoog (MS) media supplemented with different concentrations and combinations of 6-benzylaminopurine (BAP), isopentenyl adenine (2ip), thidiazuron (TDZ), and naphthalene acetic acid (NAA). Direct organogenesis was induced on half and full-strength MS media supplemented with TDZ (0.7 to $3.5 \mathrm{mg} / \mathrm{l})$ from leaf and petiole explants. Indirect shoot organogenesis was induced on half-strength MS supplemented with $3.5 \mathrm{mg} / 1$ 2ip and $2.5 \mathrm{mg} / 1 \mathrm{NAA}$ followed by transferring the obtained callus onto a half-strength MS containing $0.5 \mathrm{mg} / 1 \mathrm{BAP}$. The highest frequency of shoot organogenesis (100 and $86.66 \%$ ) was noted for petiole and leaf explants, respectively, on halfstrength MS medium supplemented with $2.8 \mathrm{mg} / 1 \mathrm{TDZ}$ (approx. 7.66 and 4.33 shoots per petiole and leaf explant, respectively). The induced shoots were used for root induction on a half-strength MS medium with $0.5 \mathrm{mg} / \mathrm{lin}$ dole-3-butyric acid (IBA). Phytochemical constituents in leaf tincture were determined by gas chromatography/mass spectrometry (GC/MS) analysis. GC/MS results revealed that vitamin $\mathrm{E}$ was the main component in the tincture of Viola leaves. The present study provides a simple and rapid protocol for in vitro regeneration of $V$. caspia subsp. sylvestrioides plants which can be used for gene transfer and conservation purposes, and in pharmaceutical studies.
\end{abstract}

Key words: GC/MS analysis, organogenesis, thidiazuron, Viola, vitamin $\mathrm{E}$

\section{Introduction}

Viola caspia (Rupr.) Freyn. is a perennial plant that requires cool, moist, shady habitats with humus-rich soil for growth. The species is octoploid with chromosome number $2 n=8 x=40$ (Marcussen and Borgen, 2011a). Plants develop insect-pollinated chasmogamous flowers which are replaced by seasonal cleistogamic flowers later in the season. Both flower types develop capsules fulfilled with seeds (Marcussen and Borgen, 2011a).

Based on the petal color, Viola caspia (Rupr.) Freyn is divided in two subspecies: V. caspia subsp. sylvestrioides Marcussen and V. caspia subsp. caspia. The sylvestrioides petal color is lavender blue (Fig. $1 \mathrm{~A}$ ) and it grows 1700-1800 m above the sea level in Ardebil, in the north-west of Iran (Yousefi et al., 2012). V. caspia subsp. caspia has whitish corollas and grows $300-400 \mathrm{~m}$ above the sea level in Lahijan, Guilan, in the north of Iran (Yousefi et al., 2012; Saeidi Mehrvarz et al., 2013).

Two taxa often grow in the same habitats in mixed populations, but there is no evidence of gene flow between these two subspecies. Intraspecific variation in V. caspia, based on allozyme analysis, showed that two corolla color morphs differ considerably in their allozyme multilocus profiles (Marcussen and Borgen, 2011a).

V. caspia subsp. sylvestrioides belongs to subsection Rostratae Kupffer W. Becker, of the genus Viola (Viola-

\footnotetext{
* Corresponding author: Department of Plant Production and Genetics, Faculty of Agriculture, University of Zanjan, Zanjan, Iran; e-mail: zahraghrr112@gmail.com
} 
ceae), that is commonly known as "Banafshe" in Persian and is an important small, ornamental, perennial medicinal herb restricted to northeastern Crimea, Turkey, Caucasus and the Caspian coast (Marcussen et al., 2011b). The whole plant is medicinally useful. The herbal tea of this plant is an expectorant, and the oil can be used for treating sinusitis, migraine, and headache (Zargari, 1997).

The Violaceaefamily includes species biosynthesizing cyclotides, flavonoids, alkaloids, saponins, tannins, coumarins, and salicylates. In traditional medicine viola is used to treat cough, asthma, and catarrhal and pulmonary problems (Pullaiah, 2006; Vohora, 1986). Metabolites of Viola have a wide range of biological activities and pharmacological applications, such as anti-cancer (Gerlach et al., 2010), anti-inflammatory (Koocheck et al., 2003), anti-viral (Hallock et al., 2000), antibacterial (Gruber et al., 2007), and antioxidant properties (Stojkovic et al., 2011), together with antifouling activities (Göransson et al., 2004), cytotoxic effects (Lindholm et al., 2002), and anti-bronchitis activity (Karnick, 1996).

These medicinal properties make Viola matebolites potential candidates for pharmaceutical and biotechnological studies. In recent years, there has been much progress in the understanding of the molecular regulation of the biosynthesis of secondary metabolites (Staniek et al., 2013). However, the lack of effective protocols for in vitro regeneration and genetic transformation of plants has limited the efforts of its regulation. The low seed germination percentage and a long dormancy period of viola limit its propagation by seeds. Moreover, in recent times $V$. caspia subsp. sylvestrioides has been found to be threatened in its habitats in Iran due to severe grazing and its excessive use (by people) in traditional medicine. Hence callus culture, plant regeneration, and micropropagation techniques could be considered as alternative methods for its conservation. Also, one of the benefits of in vitro regeneration is that both, the regenerated plants and the callus, can be used as a source of important bioactive metabolites. Therefore, an efficient protocol is necessary for successful tissue culture and plant regeneration of Viola. In recent years there have been some effective reports on plant regeneration of the Viola species (Chalageri and Babu, 2012; Kaloo et al., 2013; Vishwakarma et al., 2013; Slazak et al., 2015; Żabicki et al., 2019), but there is no report on tissue culture and plant regeneration of $V$. caspia subsp. sylvestrioides. In this study we aimed at obtaining an efficient shoot regeneration protocol of $V$. caspia subsp. sylvestrioides under in vitro conditions using leaf and petiole explants and assessing the secondary metabolites in leaf extracts by gas chromatography/mass spectrometry (GC/MS) analysis.

\section{Materials and methods}

\section{Plant material and seed germination}

Seeds of $V$. caspia subsp. sylvestrioides were collected from Almas road, Ardebil, Iran (the plants were identified by Dr. Shahryar Saeidi Mehrvarz, associate professor of botany, University of Guilan, Rasht, Iran). They were subsequently scarificated with $95 \%$ sulfuric acid for 8 min for breaking the dormancy, and after that, were sterilized with $10 \%$ sodium hypochlorite solution containing one drop of Tween- 20 for 8 min and rinsed four times in sterile distilled water. For germination, the seeds were planted in glass bottles containing $30 \mathrm{ml}$ of quarter-strength MS medium supplemented with $3 \%$ sucrose and $0.7 \%$ agar at a $\mathrm{pH}$ of 5.6-5.8 and were incubated with $16 \mathrm{~h}$ light photoperiod $\left(35 \mu \mathrm{mol} \mathrm{m}{ }^{-2} \mathrm{~s}^{-1}\right)$ inside a growth chamber at a temperature of $24-25^{\circ} \mathrm{C}$.

\section{In vitro tissue culture and shoot organogenesis}

The explants, including petiole segments $(1 \mathrm{~cm})$ and leaf blades $(1 \times 1 \mathrm{~cm})$, were obtained from two-month old seedlings. For regeneration, two separate experiments were carried out. The first experiment was carried out to evaluate the effects of benzylaminopurine (BAP), isopentenyl adenine (2ip) (cytokinins), and, NAA (auxin) on callus induction and regeneration. Leaf and petiole explants were placed horizontally with the adaxial surface toward the media for callus and/or shoot induction. For this purpose, a half-strength MS medium was supplemented with BAP or 2ip at $2,2.5$, and $3 \mathrm{mg} / \mathrm{l}$ in combination with NAA $(2,2.5$, and $3 \mathrm{mg} / \mathrm{l})$. The rate of callus induction on explants was evaluated in the primary culture. Then the explants producing callus were subcultured in half-strength MS medium containing $0.5 \mathrm{mg} / 1 \mathrm{BAP}$ (for shoot induction) and after two successive passages, the induced shoots were cultivated on quarter-strength MS medium.

In the second experiment, petiole and leaf explants were prepared as described above. Explants were cultured in half and full-strength MS media solidified with 
$0.7 \%$ agar and supplemented with $\mathrm{TDZ}$ at concentrations of $0,0.7,1.4,2.1,2.8$, or $3.5 \mathrm{mg} / 1$. In both experiments, two parameters were evaluated: the frequency of regeneration and the number of shoots per explant.

\section{Root induction and acclimatization}

Four-week-old shoots (approx. $3 \mathrm{~cm}$ long) were transferred individually into a half-strength MS medium containing $0.5 \mathrm{mg} / 1 \mathrm{IBA}$. In vitro-rooted shoots were taken out from the culture bottles and washed using sterile warm water to remove the solid media attached to the roots. The plantlets were transplanted into pots containing a mixture of soil, peat moss, and sand $(4: 3$ : $3 \mathrm{w} / \mathrm{w} / \mathrm{w}$ ) autoclaved at $121^{\circ} \mathrm{C}$ for $25 \mathrm{~min}$. Individual potted plants were kept covered with transparent polyethylene bags, to maintain a relatively high humidity level during the initial stages of pre-hardening, at $3000 \mathrm{Lux}$ and $16 \mathrm{~h}$ photoperiod at $24-25^{\circ} \mathrm{C}$ in a growth chamber for two weeks. Then, the transparent polyethylene bags were gradually opened and removed between 14-18 days after the hardening was complete. After two months, at the beginning of spring, these plantlets were transferred to field conditions.

\section{GC/MS analysis of $V$. caspia subsp. sylvestrioides tincture}

For the GC/MS analysis, the plant leaves were thoroughly washed to remove dust particles and then air dried at room temperature. Immediately after drying, $2.5 \mathrm{~g}$ of leaves were powdered using an electric mixergrinder and sieved through a BSS mesh (no. 85 sieve). The sieved powder was extracted with $50 \mathrm{ml}$ ethanol. The tincture was filtered and kept at $4{ }^{\circ} \mathrm{C}$ before injecting into GC.

The tincture was analyzed by a GC/MS (Agilent 6890 GC), equipped with a Rtx-5 capillary column of $30 \mathrm{~m}$ length $\times 0.25 \mathrm{~mm}$ inner diameter (ID) and $0.25 \mu \mathrm{m}$ stationary phase film thickness, with an Agilent 5973 mass selective detector. The column temperature range was $40^{\circ} \mathrm{C}$ (holding time for $1 \mathrm{~min}$ ) to $240^{\circ} \mathrm{C}$ (holding time $5 \mathrm{~min}$ ) varied at $3^{\circ} \mathrm{C} \mathrm{min}^{-1}$. Helium was used as the carrier gas. For GC/MS detection, an electrospray ionization (ESI) system with an ionization energy of $70 \mathrm{eV}$ was used. The injector temperature was $250^{\circ} \mathrm{C}$ and injection volume was $1 \mu \mathrm{l}$. The components were identified by comparing their relative retention times with those of authentic samples on the HP-5 MS capillary column and also by comparing their mass spectra with those in the GC/MS library and literature (Adams, 2007).

\section{Experimental design and statistical analysis}

A factorial experiment, based on a completely randomized design with three replicates and 10 explants in each replicate, was used. The effect of different treatments was compared by Duncan's multiple range tests with a confidence level of $P \leq 0.01$. Statistical analysis and means comparison were done using the IBM SPSS Statistics 22.0 software.

\section{Results}

\section{Tissue culture and plant regeneration}

\section{First experiment}

In the preliminary experiments, Viola plants were growing well when their seeds were cultured on half, instead of a full-strength, MS medium. Therefore, for further experiments, all explants were cultivated on halfstrength MS medium. Callus induction occurred along the edges of explants (petioles and leaves) within 3 weeks of culture on all the tested media (Fig. 2A, Fig. B). The use of 2ip in comparison with BAP resulted in a high percentage of callus-producing explants (Table 1 ). In the medium containing 2ip and NAA, the frequency of callus induction in the leaf explants was higher than in petiole explants $\left(93.33 \pm 5.77^{\mathrm{a}}\right.$ and 80.00 $\pm 10.00^{\mathrm{b}}$ ) respectively, for leaf and petiole explants in a medium containing $3 \mathrm{mg} / \mathrm{l} 2 \mathrm{ip}$ and NAA). However, in the medium containing BAP and NAA, it was higher in the petiole explants $\left(63.33 \pm 5.77^{\text {ab }}\right.$ and $46.66 \pm 5.77^{\mathrm{a}}$, respectively, for petiole and leaf explants in a medium containing $2.5 \mathrm{mg} / 12 \mathrm{ip}$ and $3 \mathrm{mg} / \mathrm{l} \mathrm{NAA}$ ). Shoot organogenesis was observed only on the medium containing $3 \mathrm{mg} / 12 \mathrm{ip}$ and $2.5 \mathrm{mg}$ NAA after 2 months of culture (Fig. 2C). In this medium, the frequency of shoot organogenesis for leaf and petiole explants was $60 \%$ and $50 \%$, respectively. Also, the frequency of shoot induction was 3.2 shoots per leaf and 2.7 shoots per petiole explant. Overall, with respect to shoot organogenesis and the frequency of shoot induction per explant, leaf explants are more productive than petiole explants. When explants were not cultured on a medium containing plant growth regulators, neither callus nor shoots were induced. 


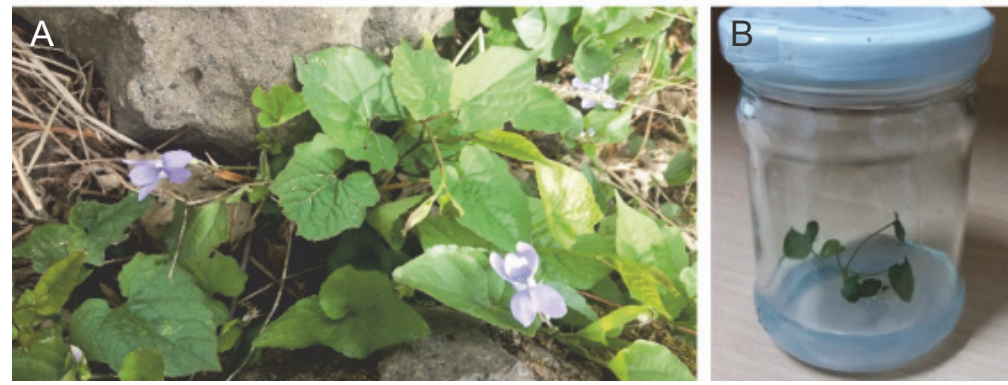

Fig. 1. A) Viola caspia subsp. sylvestrioides in nature, B) in vitro germinated seedlings from seeds
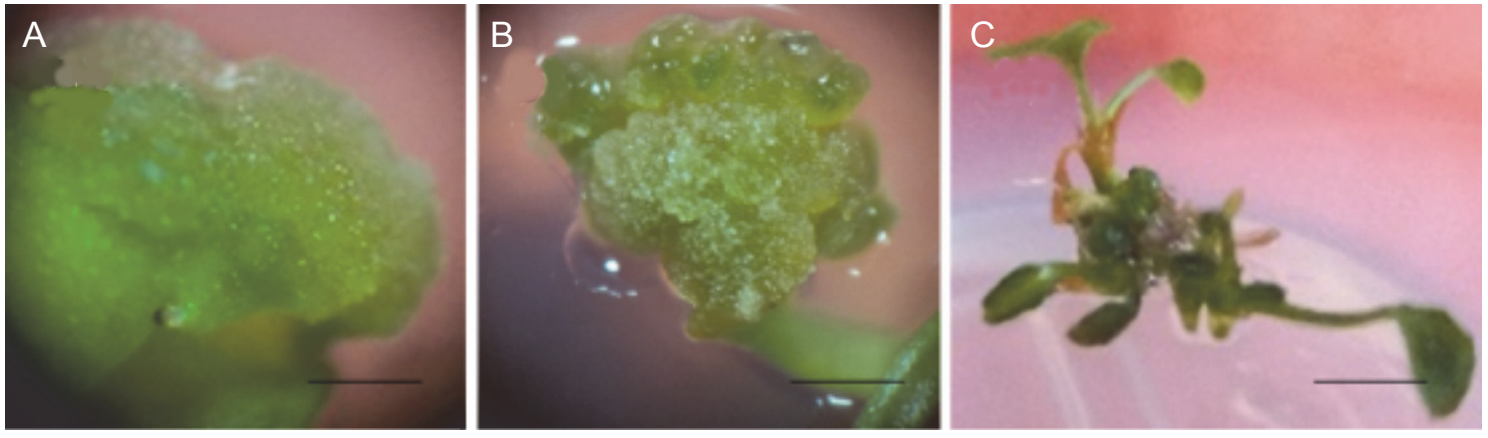

Fig. 2. Callogenesis and regeneration of $V$. caspia subsp. sylvestrioides via leaf and petiole explants on Murashige and Skoog (MS) medium containing isopentenyl adenine and naphthalene acetic acid; A) induction of callus from leaf, B) petiole, C) shoot regeneration from petiole explants; bars $(\mathrm{a}=0.8 \mathrm{~mm}, \mathrm{~b}=1 \mathrm{~mm}, \mathrm{c}=2 \mathrm{~mm})$

\section{Second experiment}

During the second part of this study, shoots were developed directly from petiole and leaf explants (Fig. 3) on half and full-strength MS media, supplemented with TDZ alone in different concentrations, for a duration of 4 weeks. The half-strength MS medium supplemented with TDZ was more effective in promoting shoot development than the full-strength MS medium supplemented with the same concentration of TDZ. For leaf explants, there was no significant difference in shoot induction between the tested media with either full-or halfstrength MS medium except for $2.8 \mathrm{mg} / 1$ (approximately $66.6 \%$ and $86.6 \%$, respectively in full-and half-strength MS) and $2.1 \mathrm{mg} / 1$ (approximately $43.3 \%$ and $50 \%$, respectively in full and half-strength MS). For petiole explants, there was a significant difference in shoot induction due to TDZ concentrations in full-strength MS medium (Fig. 4). The highest frequency of shoot organogenesis, $100 \%$ and $86.66 \%$, was observed in petiole and leaf explants, respectively, on the half-strength MS medium supplemented with $2.8 \mathrm{mg} / \mathrm{l} \mathrm{TDZ}$, but this was not significantly different from shoots derived from pe- tioles with $2.1 \mathrm{mg} / 1 \mathrm{TDZ}$ (Fig. 4A). With higher TDZ concentrations $(3.5 \mathrm{mg} / \mathrm{l})$, low frequencies of shoot organogenesis were observed in leaf and petiole explants (as compared to other media). For leaf explants, frequencies of shoot organogenesis were approximately $46.6 \%$ and $36.6 \%$, respectively on full and half-strength MS media; however for petiole explants they were $36.6 \%$ and $50 \%$, respectively, in full and half-strength MS media (Fig. 4A).

\section{Frequency of shoot induction per explant}

The number of shoots per leaf explant increased with TDZ concentration ranging from 0.7 to $2.8 \mathrm{mg} / \mathrm{l}$, with either half-or a full-strength MS medium. The highest number of shoots (7.66 shoots) was obtained in leaf explants on the medium containing half-strength MS with $2.8 \mathrm{mg} / \mathrm{l} \mathrm{TDZ}$ (Fig. 4B). For petiole explants, the highest number of shoots (4.33 shoots) was obtained on the medium containing half-strength MS with $2.8 \mathrm{mg} / \mathrm{l} \mathrm{TDZ}$ (Fig. 4B). The induced shoots rooted on half-strength MS medium containing $0.5 \mathrm{mg} / 1 \mathrm{IBA}$ (Fig. $3 \mathrm{~F}$ ). All plants regenerated in vitro were acclimatized after two months 
Table 1. Effect of isopentenyl adenine (2ip), benzylaminopurine (BAP), and naphthalene acetic acid (NAA) on the frequency of callus induction from petiole and leaf explants of $V$. caspia subsp. sylvestrioides on half-strength Murashige and Skoog (MS) medium

\begin{tabular}{|c|c|c|c|c|}
\hline \multirow{2}{*}{ Medium } & \multirow{2}{*}{$\underset{[\mathrm{mg} / \mathrm{l}]}{2 \mathrm{ip}}$} & \multirow{2}{*}{$\begin{array}{c}\mathrm{NAA} \\
{[\mathrm{mg} / \mathrm{l}]}\end{array}$} & \multicolumn{2}{|c|}{ Rate of callus formation [\%] } \\
\hline & & & leaf & petiole \\
\hline 1 & 2.00 & 2.00 & $16.66 \pm 5.77^{\mathrm{f}}$ & $13.33 \pm 5.77^{\mathrm{d}}$ \\
\hline 2 & 2.00 & 2.50 & $36.66 \pm 5.77^{d}$ & $23.33 \pm 5.77^{\mathrm{cd}}$ \\
\hline 3 & 2.00 & 3.00 & $53.33 \pm 5.77^{\mathrm{c}}$ & $43.33 \pm 5.77^{\mathrm{b}}$ \\
\hline 4 & 2.50 & 2.00 & $23.33 \pm 5.77^{\mathrm{ef}}$ & $16.66 \pm 5.77^{d}$ \\
\hline 5 & 2.50 & 2.50 & $43.33 \pm 5.77^{\mathrm{cd}}$ & $26.66 \pm 5.77^{\mathrm{cd}}$ \\
\hline 6 & 2.50 & 3.00 & $80.00 \pm 10.00^{b}$ & $73.33 \pm 15.27^{\mathrm{a}}$ \\
\hline 7 & 3.00 & 2.00 & $33.33 \pm 5.77^{\text {de }}$ & $20.00 \pm 0.00^{\mathrm{cd}}$ \\
\hline 8 & 3.00 & 2.50 & $53.33 \pm 5.77^{\mathrm{c}}$ & $33.33 \pm 5.77^{\mathrm{bc}}$ \\
\hline 9 & 3.00 & 3.00 & $93.33 \pm 5.77^{\mathrm{a}}$ & $80.00 \pm 10.00^{a}$ \\
\hline \multirow[t]{2}{*}{$\mathrm{MS}^{*}$} & 0.00 & 0.00 & $00.00 \pm 0.00$ & $00.00 \pm 0.00$ \\
\hline & $\mathrm{BA}[\mathrm{mg} / \mathrm{l}]$ & $\mathrm{NAA}[\mathrm{mg} / \mathrm{l}]$ & leaf & petiole \\
\hline 1 & 2.00 & 2.00 & $0.00 \pm 0.00^{\mathrm{d}}$ & $10.00 \pm 10.00^{\mathrm{f}}$ \\
\hline 2 & 2.00 & 2.50 & $16.66 \pm 5.77^{\mathrm{c}}$ & $46.66 \pm 5.77^{d}$ \\
\hline 3 & 2.00 & 3.00 & $36.66 \pm 5.77^{\mathrm{b}}$ & $56.33 \pm 5.77^{\mathrm{abc}}$ \\
\hline 4 & 2.50 & 2.00 & $3.33 \pm 5.77^{\mathrm{d}}$ & $23.33 \pm 5.77^{\mathrm{e}}$ \\
\hline 5 & 2.50 & 2.50 & $23.33 \pm 5.77^{\mathrm{c}}$ & $50.00 \pm 0.00^{d}$ \\
\hline 6 & 2.50 & 3.00 & $46.66 \pm 5.77^{\mathrm{a}}$ & $63.33 \pm 5.77^{\mathrm{ab}}$ \\
\hline 7 & 3.00 & 2.00 & $6.66 \pm 5.77^{\mathrm{d}}$ & $33.33 \pm 5.77^{\mathrm{e}}$ \\
\hline 8 & 3.00 & 2.50 & $33.33 \pm 5.77^{b}$ & $53.33 \pm 5.77^{\mathrm{cd}}$ \\
\hline 9 & 3.00 & 3.00 & $53.33 \pm 5.77^{\mathrm{a}}$ & $66.66 \pm 5.77^{\mathrm{a}}$ \\
\hline MS* & 0.00 & 0.00 & $00.00 \pm 0.00$ & $00.00 \pm 0.00$ \\
\hline
\end{tabular}

Data are from three independent experiments; * the medium was used as a control
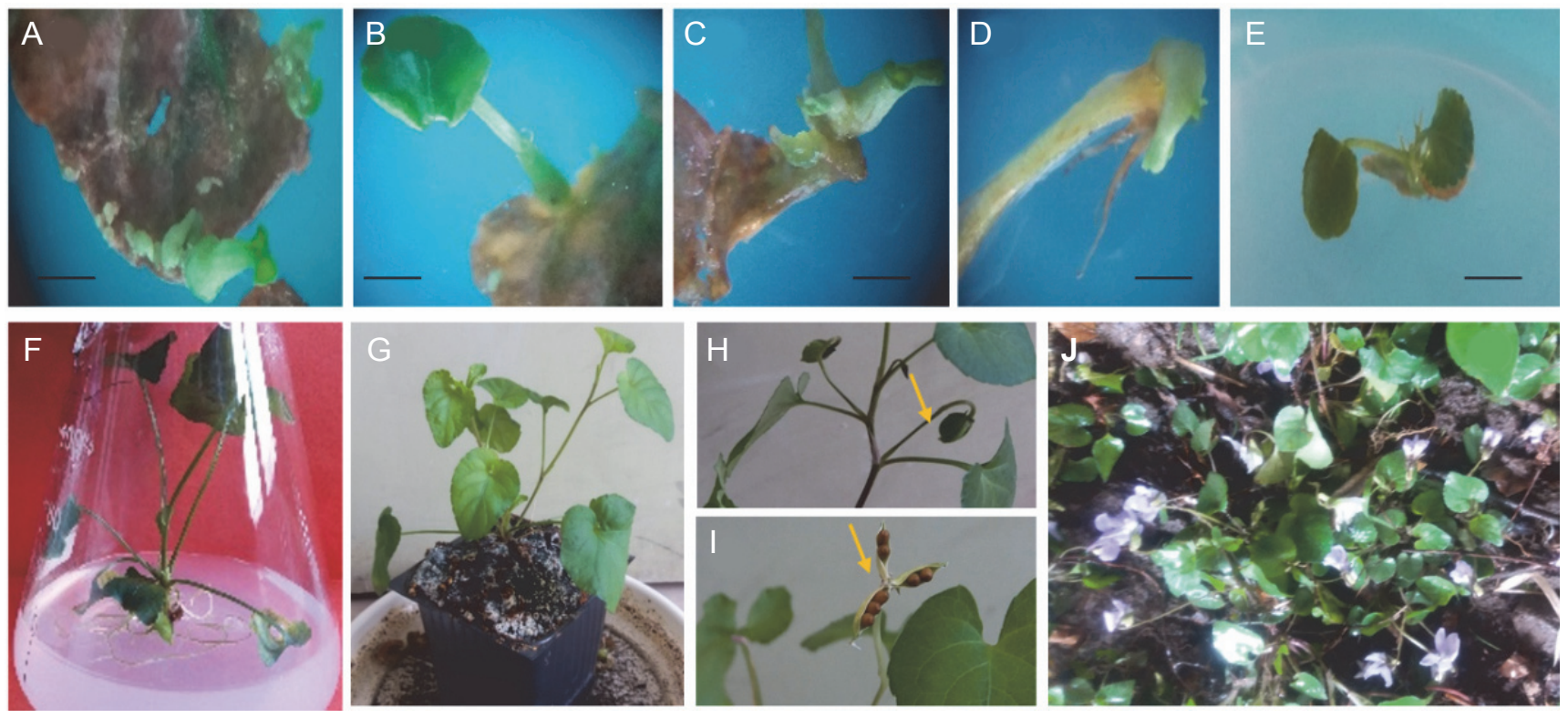

Fig. 3. Direct organogenesis of $V$. caspia subsp. sylvestrioides; A) and B) direct shoot formation from leaf lamina explants and C) and D) petiole explants; E) shoot formation from leaf explant after 3 weeks; F) rooted shoot after 2 weeks of culture on halfstrength MS medium supplemented with $0.5 \mathrm{mg} / 1$ indole-3-butyric acid; G) acclimatized in vitro plant after 1 month of culture in the greenhouse; $\mathrm{H}$ ) regenerated plantlets with capsules developed from cleistogamous flowers; I) opened, tripartite capsule, visible seeds; J) plants acclimatized to the field conditions after 1 year; bars $(a=1 \mathrm{~mm}, \mathrm{~b}=2 \mathrm{~mm}, \mathrm{c}=1 \mathrm{~mm}, \mathrm{~d}=2 \mathrm{~mm}, \mathrm{e}=5 \mathrm{~mm})$ 
A

Regeneration

MS $\quad 1 / 2 \mathrm{MS}$

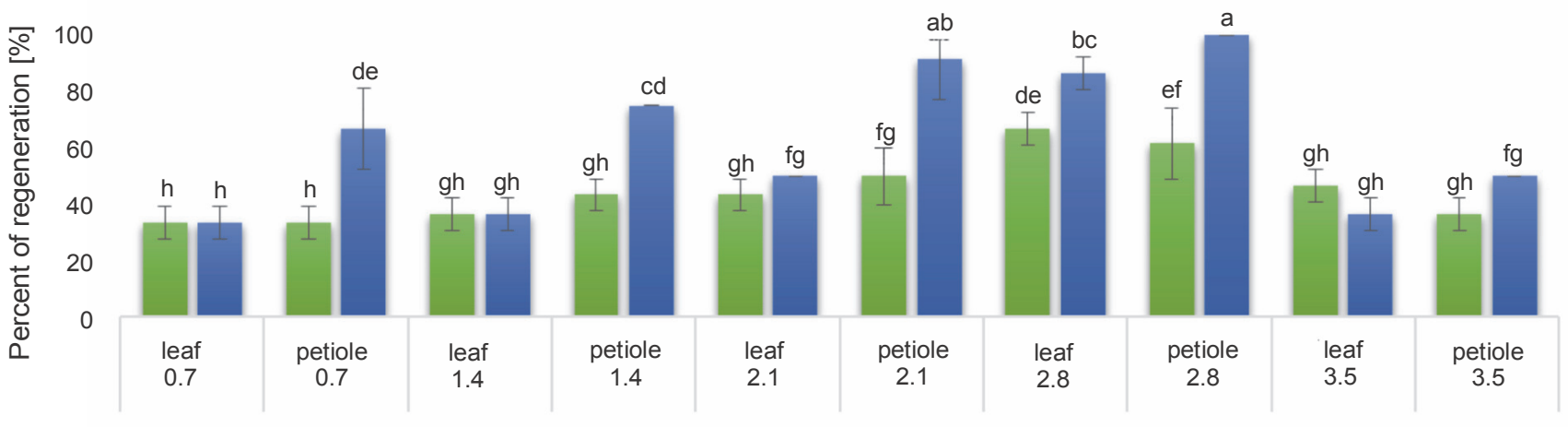

TDZ [mg/l] and explant

B

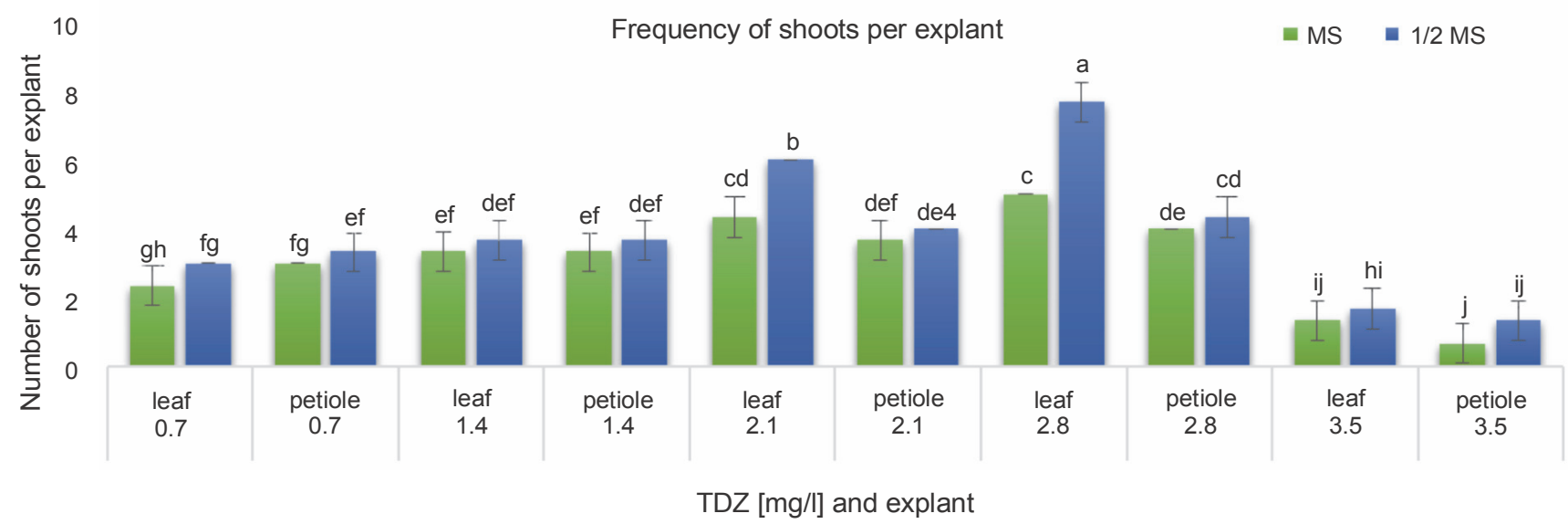

Fig. 4. Effect of thidiazuron concentration, explant type and MS strength on shoot organogenesis and the frequency of shoot induction per leaf and petiole explant of $V$. caspia subsp. sylvestrioides. A) shoot organogenesis frequency; B) frequency of shoot induction per explant

Table 2. Chemical composition and percentage of compounds in leaf tincture of $V$. caspia subsp. sylvestrioides

\begin{tabular}{|c|c|c|c|}
\hline Peak & Compounds & $\begin{array}{c}\text { Retention } \\
\text { time } \\
\text { [min] }\end{array}$ & $\begin{array}{c}\text { Percent } \\
\text { of total } \\
{[\%]}\end{array}$ \\
\hline 1 & Ethyl iso-allocholate & 30.135 & 1.289 \\
\hline 2 & 1,2-benzenedicarboxylic acid, dinonyl ester & 31.347 & 24.19 \\
\hline 3 & Vitamin E & 35.028 & 35.257 \\
\hline 4 & Phthalic acid, bis(7-methyloctyl) ester & 42.406 & 17.232 \\
\hline 5 & $\begin{array}{l}\text { 2,4,6-decatrienoic acid, 1a,2,5,5a,6,9,10,10a-octahydro-5,5a-dihydroxy-4-(hydroxymethyl)- } \\
\text { 1,7,9-trimethyl-1- }\end{array}$ & 42.850 & 16.402 \\
\hline 6 & Docosanoic acid, 1,2,3-propanetriyl ester & 43.851 & 3.116 \\
\hline 7 & $\begin{array}{l}\text { D-homo-24-nor-17-oxachola-1,20,22-triene-3,16-dione,7-(acetyloxy)-14,15:21,23-diepoxy-4,4,8- } \\
\text { trimethyl-, }\end{array}$ & 44.084 & 2.514 \\
\hline
\end{tabular}

in the greenhouse (Fig. 3G). In the greenhouse and under field conditions, they produced chasmogamous and clestogamous flowers and capsules filled with seeds (Fig. 3I, Fig. 3J).

\section{GC/MS analysis of the leaf tinctures}

The GC/MS analysis of the leaf tinctures resulted in the identification of 7 different compounds (Table 2). The identified constituents of the tincture are listed in 
Table 2 and are presented in order of their retention times. The main compounds found were vitamin $\mathrm{E}$ (35.257\%) and 1,2-benzenedicarboxylic acid, dinonyl ester (24.19\%), while ethyl iso-allocholate and D-homo24-nor-17-oxachola-1,20,22-triene-3,16-dione,7-(acetyloxy)-14,15:21,23-diepoxy-4,4,8-trimethyl-, were found in small quantities (1.289\%, and 2. 514\%, respectively).

\section{Discussion}

In recent years the use of different cytokinins including BAP, kinetin (KIN) and TDZ has been reported for the regeneration and micropropagation of Viola plants (Slazak et al., 2015, Żabicki et al., 2019). Our results show that petiole and leaf explants regenerated with 2ip at $3 \mathrm{mg} / \mathrm{l}$ and NAA at $2.5 \mathrm{mg} / 1$ (Fig. $2 \mathrm{C}$ ). The results (also) revealed that a higher concentration of 2ip (3 $\mathrm{mg} / \mathrm{l})$ was more effective in callus proliferation and the regeneration of explants. Similar observations have also been made by Chaudhuri et al. (2004) in Tylophora indica.

$\mathrm{TDZ}$, a diphenyl urea derivative, is involved in the biosynthesis of auxin with increasing levels of indole-3acetic acid (IAA) and its precursor (tryptophan) (Murthy et al., 1998). In many plant species, TDZ appeared as a potent bioregulant in cell and tissue cultures (Yancheva et al., 2003; Matand and Prakash, 2007). Depending on the genotype of plants and the type of explants, TDZ induces different regeneration responses (Passey et al., 2003). TDZ, with a high cytokinin-like activity (Huetteman and Preece, 1993), is widely used to promote shoot proliferation in many plant species, including the members of Violaceae (Sato et al., 1995; Slazak et al., 2015; Żabicki et al., 2019). The study by Slazak et al. (2015) revealed that TDZ had the potential to induce direct and indirect organogenesis in leaf and petiole explants of Viola uliginosa Besser (Slazak et al., 2015). The authors also reported that organogenesis was induced in leaf and petiole fragments with a combination of KIN and 2,4-D, followed by a callus transfer on TDZ (Slazak et al., 2015). In the current study, the different concentrations of TDZ, the type of explants and the strength of the MS medium proved to be important factors affecting the frequency of shoot regeneration. Petiole explants and half-strength MS medium $(2.8 \mathrm{mg} / \mathrm{l})$ were more productive in efficient shoot organogenesis in Viola caspia subsp. sylvestrioides, in agreement with previously re- ported results on Viola wittrockiana (Sato et al., 1995), where it was shown that multiple shoot organogenesis could be achieved from petiole callus using a halfstrength MS medium supplemented with BAP in combination with NAA. The number of regenerated shoots formed on leaf explants was greater than the number of shoots obtained on petiole explants (approx. 7.6 and 4.3 shoots per explant, respectively, for leaf and petiole explants on a medium containing $2.8 \mathrm{mg} / \mathrm{l} \mathrm{TDZ}$ ), which was consistent with the results obtained by Slazak et al. (2015).

Over the past decades, efforts have been made to extract secondary metabolites of medicinal plants, elucidate their structure and evaluate their biological activity. When natural resources are limited or a chemical synthesis is impossible, plant cell tissue culture techniques appear to be eco-friendly, alternative methods for the production of secondary metabolites. Also, in many instances it is difficult to cultivate plant species with traditional methods, or it takes a long time, frequently, several years (Greger, 2017). The excessive exploitation of medicinal plants from wild populations in their natural habitats for medical and industrial purposes and insufficient cultivation fields have led to the reduction of biodiversity and depletion of natural populations of these plants. Therefore, various sets of biotechnical approaches, such as in situ and ex situ conservation methods (Huang, 2011; Liu et al., 2011), should be applied to improve the yields of medicinal plants.

Herb preparation and extraction methods are the main steps in bioactivity testing and chemical identification of biologically active ingredients of medicinal herbs. In traditional medicine, Viola tinctures are used for the treatment of colds and bronchitis. Recently Hellinger et al. (2014) reported that the tincture of Viola tricolor inhibited the proliferation of activated lymphocytes. Also, it negatively affected other hyper-responsive immune functions, like the effector function, by reducing IFN- $\gamma$ and producing TNF- $\alpha$ (Hellinger et al., 2014). GC/MS results of $V$. caspia subsp. sylvestrioides tincture showed that it contained a high amount of biologically active compounds such as vitamin $\mathrm{E}$ and 1,2-benzenedicarboxylic acid and dinonyl ester. Vitamin $\mathrm{E}$ is one of the lipid-soluble components in the antioxidant defense system of cells. It carries out numerous, significant biological activities in the body due to its role in the preven- 
tion of oxidative stress (Burton et al., 1983), protection of cell membranes (Howard et al., 2011), regulation of platelet aggregation and protein kinase $\mathrm{c}$ activation ( $\mathrm{Li}$ et al., 2001), and prevention of diseases such as cardiovascular (McAnally et al., 2007) and Alzheimer's diseases (Mangialasche et al., 2013), and cancer (Wells et al., 2010). The presence of high amounts of vitamin $\mathrm{E}$ in the $V$. caspia subsp. sylvestrioides tinctures indicates that viola species may be are useful in the therapy of most disorders. This regeneration protocol can produce large populations of these plants which will be useful for the extraction of these pharmaceutical compounds.

\section{Conclusion}

This study has developed an efficient, effective, and reproducible protocol for direct and indirect shoot organogenesis of $V$. caspia subsp. sylvestrioides. In addition, the tincture obtained from $V$. caspia subsp. sylvestrioides leaves contains high amounts of biologically active compounds such as vitamin $\mathrm{E}$. To conclude, the present study can contribute to the mass propagation of V. caspia subsp. sylvestrioides for ex situ conservation purposes, gene transformation goals, production of large amounts of pharmaceutical compounds and commercial cultivation. The acclimatized in vitro-obtained plants can also be used as alternatives to wild populations of $V$. caspia subsp. sylvestrioides.

\section{Acknowledgments}

The authors would like to thank the authorities of the Faculty of Pharmacy, Zanjan University of Medical Sciences, for their support.

\section{References}

Adams R.P. (2007) Identification of essential oil components by gas chromatography/mass spectrometry. Carol Stream: Allured Publishing Corporation.

Burton G.W., Joyce A., Ingold K.U. (1983) Is vitamin $E$ the only lipid-soluble, chain-breaking antioxidant in human blood plasma and erythrocyte membranes?Arch. Biochem. Biophys. 221: 281-290.

Chalageri G., Babu U.V. (2012) In vitro plant regeneration via petiole callus of Viola patrinii and genetic fidelity assessment using rapd markers. Turk. J. Bot. 36: 358-368.

Chaudhuri K., Ghosh B., Jha S. (2004) The root: a potential new source of competent cells for high-frequency regeneration in Tylophora indica. Plant. Cell. Rep. 22: 731-740.

Gerlach S.L., Rathinakumar R., Chakravarty G., Göransson U., Wimley W.C., Darwin S.P., Mondal D. (2010) Anticancer and chemosensitizing abilities of cycloviolacin 02 from
Viola odorata and Psyle Cyclotides from Psychotria leptothyrsa. Biopolymers 94: 617-625.

Göransson U., Sjögren M., Svangård E., Claeson P., Bohlin L. (2004) Reversible antifouling effect of the cyclotide cycloviolacin o2 against barnacles. J. Nat. Prod. 67: 1287-1290.

Greger H. (2017) Phytocarbazoles: alkaloids with great structural diversity and pronounced biological activities. Phytochem. Rev. 16: 1095-1153.

Gruber C.W., Anderson M.A., Craik D.J. (2007) Insecticidal plant cyclotides and related cystine knot toxins. Toxicon. 49: 561-575.

Hallock Y.F., Sowder R.C., Pannell L.K., Hughes C.B., Johnson D.G., Gulakowski R., Cardellina J.H., Boyd M.R. (2000) Cycloviolins a-d, anti-hiv macrocyclic peptides from Leonia cymosa. J. Org. Chem. 65: 124-128.

Hellinger R., Koehbach J., Fedchuk H., Sauer B., Huber R., Gruber C.W., Gründemann C. (2014) Immunosuppressive activity of an aqueous Viola tricolor herbal extract. J. Ethnopharmacol. 151: 299-306.

Howard A.C., McNeil A.K., McNeil P.L. (2011) Promotion of plasma membrane repair by vitamin $E$. Nat. Commun. 2: 597-605.

Huang H. (2011) Plant diversity and conservation in China: planning a strategic bioresource for a sustainable future. Bot. J. Linn. Soc. 166: 282-300.

Huetteman C.A., Preece J.E. (1993) Thidiazuron: a potent cytokinin for woody plant tissue culture. Plant. Cell. Tiss. Org. Cult. 33: 105-119.

Kaloo Z., Akhtar R., Zafrul-Haq W.B. (2013) Effect of growth regulators on the in vitro multiplication of Viola odorata. Int. J. Med. Plant. Res. 2: 187-189.

Karnick C.R. (1996) Pharmacology of Ayurvedic medicinal plants. Delhi: Shri Satguru Publications.

Koochek M.H., Pipelzadeh M.H. Mardani H. (2003) The effectiveness of Viola odorata in the prevention and treatment of formalin-induced lung damage in the rat. J. Herbs. Spices. Med. Plants. 10: 95-103.

Li D., Saldeen T., Romeo F., Mehta J.L. (2001) Different isoforms of tocopherols enhance nitric oxide synthase phosphorylation and inhibit human platelet aggregation and lipid peroxidation: implications in therapy with vitamin $E$. J. Cardiovasc. Pharmacol. Ther. 6: 155-161.

Lindholm P., Göransson U., Johansson S., Claeson P., Gullbo J., Larsson R., Bohlin L., Backlund A. (2002) Cyclotides: a novel type of cytotoxic agents. Mol. Cancer. Ther. 1: 365-369.

Liu C., Yu H., Chen S.L. (2011) Framework for sustainable use of medicinal plants in China. Plant Divers. 33: 65-68.

Mangialasche F., Westman E., Kivipelto M., Muehlboeck J.S., Cecchetti R., Baglioni M., Tarducci R., Gobbi G., Floridi P., Soininen H. (2013) Classification and prediction of clinical diagnosis of Alzheimer's disease based on MRI and plasma measures of $\alpha-\gamma$-tocotrienols and $\gamma$-tocopherol. J. Intern. Med. 273: 602-621.

Marcussen T., Blaxland K., Windham M.D., Haskins K.E., Armstrong F. (2011) Establishing the phylogenetic origin, history, and age of the narrow endemic Viola guadalupensis (Violaceae). Am. J. Bot. 98: 1978-1988. 
Marcussen T., Borgen L. (2011) Species delimitation in the Ponto-Caucasian Viola sieheana complex, based on evidence from allozymes, morphology, ploidy levels, and crossing experiments. Plant. Syst. Evol. 291: 183-196.

Matand K., Prakash C. (2007) Evaluation of peanut genotypes for in vitro plant regeneration using thidiazuron. J. Biotechnol. 130: 202-207.

McAnally J.A., Gupta J., Sodhani S., Bravo L., Mo H. (2007) Tocotrienols potentiate lovastatin-mediated growth suppression in vitro and in vivo. Exp. Biol. Med. 232: 523-531.

Murthy B., Murch S., Saxena P.K. (1998) Thidiazuron: a potent regulator of in vitro plant morphogenesis. In vitro Cell. Dev. Biol. Plant. 34: 267-275.

Passey A., Barrett K., James D. (2003) Adventitious shoot regeneration from seven commercial strawberry cultivars (fragariaxananassa duch.) using a range of explant types. Plant. Cell. Rep. 21: 397-401.

Pullaiah T. (2006) Encyclopedia of world medicinal plants. New Delhi: Regency Publications.

Saeidi Mehrvarz S., Vafi M., Marcussen T. (2013) Taxonomic and anatomical notes on Viola sect. Viola (Violaceae) in Iran. Wulfenia 20: 73-79.

Sato T., Kwon O.C., Miyake H., Taniguchi T., Maeda E. (1995) Regeneration of plantlets from petiole callus of wild Viola (Viola patrinii DC.). Plant. Cell. Rep. 14: 768-772.

Slazak B., Sliwinska E., Saługa M., Ronikier M., Bujak J., Słomka A., Göransson U., Kuta E. (2015) Micropropagation of Viola uliginosa (Violaceae) for endangered species conservation and for somaclonal variation-enhanced cyclotide biosynthesis. PCTOC 120: 179-190.

Staniek A., Bouwmeester H., Fraser P.D., Kayser O., Martens S., Tissier A., Van Der Krol S., Wessjohann L., Warzecha H. (2013) Natural products-modifying metabolite pathways in plants. Biotechnol. J. 8: 1159-1171.
Stojkovic D., Glamoclija J., Ciric A., Siljegovic J., Nikolic M., Sokovic M. (2011) Free radical scavenging activity of Viola odorata water extracts. J. Herbs. Spices. Med. Plants. 17: 285-290.

Vishwakarma U.R., Gurav A.M., Sharma P.C. (2013) Regeneration of multiple shoots from petiole callus of Viola serpens Wall. Pharmacognosy. Res. 5: 86-92.

Vohora S.B. (1986) Unani Joshandah drugs for common cold, catarrh, cough, and associated fevers. J. Ethnopharmacol. 16: 201-211.

Wells S.R., Jennings M.H., Rome C., Hadjivassiliou V., Papas K.A., Alexander J.S. (2010) $A$-, $\gamma$-and $\delta$-tocopherols reduce inflammatory angiogenesis in human microvascular endothelial cells. J. Nutr. Biochem. 21: 589-597.

Yancheva S.D., Golubowicz S., Fisher E., Lev-Yadun S., Flaishman M.A. (2003) Auxin type and timing of application determine the activation of the developmental program during in vitro organogenesis in apple. Plant. Sci. 165: 299-309.

Yousefi N., Mehrvarz S.S., Marcussen T. (2012) Anatomical studies on selected species of Viola (Violaceae). Nord. J. Bot. 30: 461-469.

Żabicki P., Sliwinska E., Mitka J., Sutkowska A., Tuleja M., Migdałek G., Żabicka J., Słomka A., Kwiatkowska M., Kuta E. (2019) Does somaclonal variation play advantageous role in conservation practice of endangered species: comprehensive genetic studies of in vitro propagated plantlets of Viola stagnina Kit. (Violaceae). Plant. Cell. Tissue. Organ. Cult. 136: 339-352.

Zargari A. (1997) Medicinal plants. Tehran: Tehran University of Medical Sciences. 